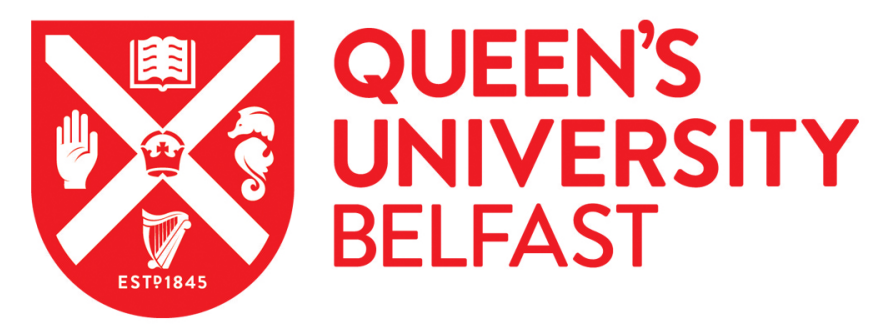

\title{
The Strengths and Limitations of the Inclusion of Religious Actors in Peace Processes in Northern Ireland and Bosnia and Herzegovina
}

Kmec, V., \& Ganiel, G. (2018). The Strengths and Limitations of the Inclusion of Religious Actors in Peace Processes in Northern Ireland and Bosnia and Herzegovina. International Negotiation, 24(1), 136. https://doi.org/10.1163/15718069-24011143

Published in:

International Negotiation

Document Version:

Peer reviewed version

Queen's University Belfast - Research Portal:

Link to publication record in Queen's University Belfast Research Portal

Publisher rights

(c) 2018 Brill Academic Publisher. This work is made available online in accordance with the publisher's policies. Please refer to any applicable terms of use of the publisher.

\section{General rights}

Copyright for the publications made accessible via the Queen's University Belfast Research Portal is retained by the author(s) and / or other copyright owners and it is a condition of accessing these publications that users recognise and abide by the legal requirements associated with these rights.

Take down policy

The Research Portal is Queen's institutional repository that provides access to Queen's research output. Every effort has been made to ensure that content in the Research Portal does not infringe any person's rights, or applicable UK laws. If you discover content in the Research Portal that you believe breaches copyright or violates any law, please contact openaccess@qub.ac.uk. 


\title{
The Strengths and Limitations of the Inclusion of Religious Actors in Peace Processes in Northern Ireland and Bosnia and Herzegovina
}

\author{
Vladimir Kmec 1 \\ University of Cambridge, UK \\ vk287@cam.ac.uk \\ Gladys Ganiel2 \\ Queen's University Belfast, Senator George J. Mitchell Institute for Global Peace, \\ Security and Justice, 19 University Square, Belfast, BT7 1NN, UK \\ G.Ganiel@qub.ac.uk
}

\begin{abstract}
This article uses a comparative approach to analyze the strengths and limitations of the inclusion of religious actors in peace and transition processes. It compares the the-oretical frameworks of Bercovitch and Kadayifci-Orellana, and Brewer, demonstrating how the first helps us understand the strengths of religious actors, while the second sheds more light on their limitations. An analysis of the involvement of religious

1 Vladimir Kmec is a Research Associate at the Von Hügel Institute at St Edmund's College at the University of Cambridge. He is a supervisor at the Department of Politics and International Studies and a coordinator of the Politics and International Relations course at Reach Cambridge Programme at the University of Cambridge.

2 Gladys Ganiel is a Research Fellow in the Senator George J. Mitchell Institute for Global Peace, Security and Justice at Queen's University, Belfast. She is author/co-author of four books and more than 30 articles and chapters on religion and conflict, evangelicalism in Northern Ireland, the emerging church, and charismatic Christianity in Zimbabwe and South Africa.
\end{abstract}


actors in peace processes in Northern Ireland and Bosnia and Herzegovina supports the argument that religious actors are more likely to contribute to peace when they are excluded from the Track One negotiations and are active in the other modali-ties of participation: in wider social peace processes at national or grassroots levels. Religious actors can contribute to peace processes especially if they choose to exclude themselves from Track One negotiations in order to avoid the pitfalls of becoming too closely associated with political power.

\section{Keywords}

faith-based negotiation - religious conflicts - Northern Ireland Bosnia and Herzegovina - religion and peace processes - religion and peacebuilding - religion and peacemaking

Religion has increasingly become a point of reference in debates on matters of peace and conflict. Between 1975 and 2010, around $\overline{30 \text { percent }}$ of armed conflicts involved religious identities, while conflicts where religion has been a factor have been on the rise since 1975 (Svensson 2012: 22, 36-37). By and large, like other civil society actors, religious actors have been excluded from the political Track One negotiations that produce peace agreements. However, religious actors have often participated in the other six of what Paffenholz (2014) describes as the seven modalities of the participation of civil society actors in negotiations: observer status, direct representation at the negotiation table, consultations, inclusive post-agreement mechanisms and commissions, highlevel problem- solving workshops, public decision making via referendum and other electoral reforms, and mass action campaigns. With an increasing emphasis on inclusive negotiations (Wanis-St. John 2006; Wanis-St. John \& Kew 2008), it is important to understand the strengths and limitations of the involvement of religious actors at multifarious stages of peace and transition processes, especially in conflicts where religion has been a factor. 
Studies of religion, conflict and peace have generally been limited to case study approaches, which have been reflected in edited volumes (Omer, Appleby\& Little 2015; Marsden 2012; Brudholm \& Cushman 2009) or reports (Silvestri \& Mayall 2015). These often include practical recommendations for policy makers about including religious actors in peace processes. However, there have been some foundational theoretical developments in the last de-cade. These push beyond general observations about the "ambivalence of the sacred" - the helpful but simple idea that religion can either be a source of conflict or a source of peace, depending on the context (Appleby 2000). This article explores two key theoretical foundations: Bercovitch and KadayifciOrellana's framework of "faith-based mediation"; and Brewer's analytical framework for "religious peacebuilding". Bercovitch and Kadayifci- Orellana's main contribution is helping us understand when faith-based actors can be es-pecially effective at mediation, which has particular relevance to the aspects of peace and transition processes focused on negotiations. They argue that faith-based mediators possess specific advantages that are not available to secular or explicitly political mediators. As a result, including them can only strengthen peace and transition processes. Yet, Bercovitch and Kadayifci- Orellana fail to adequately explore the limitations of faith-based mediators. Brewer's work provides some insights on their limitations. Working with Gareth Higgins and Francis Teeney, Brewer points out that religious peacebuilders tend to be more effective in "social" rather than "political" peace processes.4 Brewer, Higgins, and Teeney also argue that different religious actors have different levels of legitimacy, which can either enable or constrain their contributions to peace. Further, it is religious "mavericks" or representatives of "minority" rather than "majority" religions who are more likely to make constructive contributions to peace and transition processes. "Official" religious representatives - the very people who governments and political parties might seek to include in peace and transition processes - might be too constrained to take the risks necessary for peace. 
To explore how these two theoretical frameworks help us understand the strengths and limitations of religious actors in peace processes, we compare the role of religion in two cases Northern Ireland and Bosnia and Herzegovina.

The book in which this analytical framework is most fully developed was written solely by Brewer, yet Higgins and Teeney were included in authorship due to their roles in data collec-tion and commentary on drafts. Throughout we use all three authors' names when discussing the framework. But we recognize that the framework is "the most complete account of the analytical framework John Brewer has been working towards over the last decade" (Brewer, Higgins \& Teeney 2011: xiii).

These are cases of European, ethno-religious nationalism; they offer a different type of insight than studies of non-European contexts where historical rela-tionships between religion and political power and their legacies are quite dif-ferent. This makes them especially effective for understanding how religion's relationships with political power can produce different levels of legitimacy. The legacies of historical linkages between church and state, and the "religious wars" of previous centuries, coupled with a paradoxical sense that seculariza-tion can relegate religion to the margins of society, make for a complex picture. This perspective is important to contexts such as Northern Ireland and Bosnia and Herzegovina, where, despite the remaining social and cultural importance of religion, attitudes that religion cannot make constructive contributions to peace are prevalent.

The idea that religion cannot make constructive contributions to peace is an important one, particularly in a post-September 11th world where Islam is often caricatured as inherently violent. These two theoretical frameworks have particular promise because they demonstrate how religious actors can most effectively contribute to peace processes, not just in Christian contexts, but in inter-faith contexts as well. In short, including religious actors in peace and transition processes requires a careful examination of each context by tak-ing account of the varying levels of legitimacy of religious actors. Our analy-sis demonstrates that the "official" representatives of religions may not be the most effective partners for peace. Instead, religious actors are more likely to con-tribute to peace when they are excluded from direct representation in the political Track One negotiations that produce peace agreements. 
This is not a straight-forward argument for the exclusion of religious actors from peace processes; rather, we are arguing that, at the macro (state) perspective of political nego-tiations, their ability to contribute to negotiations is constrained. Including religious actors at this level would introduce an extra dynamic at the negotiation table. But this interpersonal dynamic is not what this article is about. Rather, we argue that religious actors are more likely to contribute to peace when they are active in other modalities of participation: in wider social peace processes at national or grass-roots levels. At these levels, religious actors may be engaged in macro-level social processes such as wider movements for reconciliation; or involved at the micro-level building better interpersonal relationships be-tween individuals from opposing groups. When religious actors engage in the microlevel interactions of social peace processes, they may strategically and willingly exclude themselves from direct political peace processes. As such, re-ligious actors can contribute to peace processes especially if they choose to exclude themselves from Track One negotiations in order to avoid the pitfalls of becoming too closely associated with political power.

\section{Religious Actors in Peace and Transition Processes: Theoretical Foundations}

Scholarly and public debates offer conflicting views on the role of religion in conflict and peacemaking. Samuel Huntington's (1993, 2002) "clash of civiliza-tions" presented religion - especially Islam - as a main driver of post- cold war conflicts. It has been influential in shaping the way the public and scholars have thought of the role of religion in conflict and peace. Scholars who argue that religion is a driver of conflicts often refer to religious bigotry and hatred or an incompatibility of values (Boulding 1984; Hitchens 2009; Juergensmeyer 1993, 2003; Krause 2015; Rapoport 1992). In the wake of the "clash of civiliza-tions," other scholars have demonstrated how religions contribute to peaceful resolutions of conflicts by promoting values such as justice, harmony, the absence of war, forgiveness and reconciliation (Abu-Nimer 2003; Appleby 2001; Appleby, Schreiter \& Powers 2010; Michel 2008; Sampson 1994; Sampson \& Lederach 2000; Said, Funk \& Kadayifci 2001; Gopin 2001). Some scholars high-light that religion per se does not contribute to conflict, but rather the way it 
is used (Silvestri \& James Mayall 2015; Cavanaugh 2007, 2009; Gopin 2002). Scott Appleby's term "the ambivalence of the sacred" captures how religion can serve either as a source of conflict or as a source of peace, depending on context and conditions (2000).

The study of cases where religion has contributed to peace forms the basis for a strong argument for including religious actors in negotiations, in all seven modalities of participation described by Paffenholz. We have identified two frameworks that are especially important: Bercovitch and Kadayifci-Orellana's framework of "faith-based mediation"; and Brewer, Higgins, and Teeney's "analytical framework" of religious peacebuilding. There are other frameworks we also might have profiled. For example, Weingardt (2007, 2008), in his work published in German, made arguments similar to those of Bercovitch and Kadayifci-Orellana; while Toft, Philpott, and Shah's (2011) argument about the relationship between religious and political authority has some parallels to that made by Brewer, Higgins, and Teeney about the relationship between religion and the state. However, we chose these two frameworks because of Bercovitch and Kadayifci-Orellana's emphasis on negotiations - which is of particular relevance to this special issue - and because of Brewer, Higgins, and Teeney's particular insights into how religious actors can be constrained when it comes to participating in peace and transition processes. In this article, we present all the main aspects of the two frameworks. Even though every aspect of each framework is not present in our cases of Northern Ireland and Bosnia and Herzegovina, it is important for the reader to grasp the frameworks in their entirety to understand their importance in the wider study of religion, conflict, and peacemaking.

Bercovitch and Kadayifci-Orellana provide a framework for understanding the uniqueness and effectiveness of faith-based actors. They identify six key attributes of faith-based actors, as well as conditions for effective faith-based mediation. Their identification of religious actors is wide-ranging, since they define "faith-based actors" as "organizations, institutions and individuals who are motivated and inspired by their spiritual and religious traditions, princi-ples, and values to undertake peace work" (Bercovitch \& Kadayifci-Orellana 2009: 185). This identification is wide enough to include local and international religious institutions and NGOs; as well as individual clerics and laypeople. It also could 
include politicians who are motivated by their faith. We agree with this expansive definition of religious actors. The six attributes are:

1. Legitimacy and credibility: Although academic literature often recom-mends that mediators should be neutral outsiders, in some contexts, "insider" mediators who understand the local context may be more ef-fective. Particularly in contexts where religion has been a factor, faith-based mediators are the ultimate insiders, "with the moral and spiritual legitimacy to influence the opinions of people" (Bercovitch \& KadayifciOrellana 2009: 187).

2. Leverage: In contexts where faith-based leaders are respected, they may have "unique leverage to do something about a conflict and re-frame it in ways that are acceptable to their communities" (Bercovitch \& Kadayifci-Orellana 2009: 187).

3. Financial and human resources: Faith-based mediators are able to tap into both local and international financial and human resources.

4. Time as a resource: Faith-based mediators are in it for the long haul - they were there before the negotiations began and they will remain after they end.

5. Motivation for mediation: If faith-based actors have a long and consistent history of advocating reconciliation, forgiveness, and peace, their moti-vations also are more likely to be perceived as genuine, helping them to earn trust.

6. Mediation strategies and approaches: Faith-based actors are uniquely placed to use "religious and spiritual resources such as prayers, media-tion, religious rituals, vocabulary, values, and myths" to "motivate par-ties towards an agreement and transform conflictual relationships" (Bercovitch \& KadayifciOrellana 2009: 192). In societies where religion is important, the use of religiously-tinged strategies and approaches can be especially effective.

Bercovitch and Kadayifci-Orellana's account of faith-based mediators is re-markably positive - to the extent that they might be critiqued for overlooking their limitations. Nevertheless, they also acknowledge that "faith-based media-tion cannot be effective in every conflict or in every community" (Bercovitch

\& Kadayifci-Orellana 2009: 194). To that end, they identify three conditions in which faith-based mediation is most likely to be effective:

1. Identity of the disputants: If religion is an important aspect of the iden-tities of the disputants, or the cultures/societies they 
come from, faith-based mediators are more likely to be effective.

2. Nature of the dispute: "Complex conflicts" are harder to resolve - in such cases, faith-based mediators may be able to play a role, but they are just part of a wider process.

3. History of the relationship between parties: In situations where relation-ships between conflicting parties have been longstanding and hostile, significant efforts are required to transform "negative perceptions" of the

"other." Bercovitch and Kadayifci-Orellana see faith-based mediators as uniquely placed to draw on resources from their own religious traditions to create justifications for transforming negative perceptions (2009: 197).

Bercovitch and Kadayifci-Orellana (2009: 199) conclude by arguing that faith-based mediators have the potential to make significant contributions in two main areas: 1) by bringing new dimensions of trust and legitimacy into the process, which might not be present among political parties, armed groups, and other parties to conflict; and 2) by developing common ground through inter-faith dialogue, which may then be "transferred to political leadership to exploit and expand."

Brewer, Higgins, and Teeney's analytical framework for religious peacebuild-ing provides additional tools for understanding the limitations of faith-based actors. It is most fully developed in their 2011 book, Religion, Civil Society and Peace in Northern Ireland, which is rooted in a four-year study on the role of the churches in Northern Ireland's peace process. In their discussion of the frame-work in numerous publications (Brewer, Higgins \& Teeney 2010, 2011; Brewer and Teeney 2015), they refer to the "churches" rather than "religion," reflect-ing the framework's embeddedness in the Northern Ireland case. Although the framework is generalizable to "religion," we follow their usage and refer to "churches" when outlining it.

While Bercovitch and Kadayifci-Orellana limit their analysis to "mediation," which implies quite specific types of peacebuilding activities, Brewer, Higgins, and Teeney take a more expansive approach. These differences in perspective may reflect Bercovitch and Kadayifci-Orellana's backgrounds in political sci-ence and international relations, disciplines which place more emphasis on 
mediation and negotiation; and Brewer, Higgins, and Teeney's backgrounds in sociology, a discipline which often advocates greater attention to micro-level, civil society processes. Brewer, Higgins, and Teeney push beyond Bercovitch and KadayifciOrellana's three conditions for effective faith-based mediation, shedding more light on the limitations of religious actors.

Brewer, Higgins, and Teeney's framework consists of three distinctions and two sets of relationships. The distinctions are between active and passive peacemaking, positive and negative peacemaking, and kinds of peace process-es: social and political. The first two distinctions are common in the general literature on peacemaking. Passive peacemakers talk about peace (making statements or condemning violence), while active peacemakers do something about it by participating in any number of activities these could include all of the seven modalities. Negative peace is the absence of violence, whereas positive peace involves casting a transformative vision and "working toward establishing (or reintroducing) wider principles of justice, equality, fairness and social redistribution as well" (Brewer \& Teeney 2015: 3679).

Brewer, Higgins, and Teeney define political peace processes in Track One terms: the negotiations that produce "a settlement and the monitoring of conforming to the accord afterwards:" (Brewer, Higgins \& Teeney 2011: 4-5). In contrast, social peace processes involve "the processes of social healing," namely: “... reconciliation between erstwhile protagonists, social relationship-building and repair across the communal divide, and replacement of broken-ness by the development (or restoration) of people's feelings of wholeness" (Brewer, Higgins \& Teeney 2011: 4-5). From their location within civil soci-ety, religious actors are especially wellplaced to contribute to social peace processes.

The two sets of relationships are between "church and civil society" and between "church and state." In their discussion of the relationships between church and civil society, Brewer, Higgins, and Teeney push beyond debates about "good" versus "bad" civil society, identifying "four socially strategic so-cial spaces as important to a peace process." These spaces help them to make distinctions between the types of religious actors which are most likely to occupy these spaces (i.e. traditional congregations or denominations, clergy groups, church forums, faith-based special interest groups, and so on): (Brewer, Higgins \& Teeney 2011: 133134): 
-Intellectual spaces, in which alternative ideas are envisaged and peace en-visioned, and ... [re-framed as] policy questions ...

-Institutional spaces, in which these alternatives are enacted and practiced by the civil society groups themselves ... making the groups role models and drivers of ... transformation ...

-Market spaces, in which cultural, social, and material resources are de-voted by the civil society groups ... to mobilize and articulate these alter-natives, rendering them as policy issues in the public sphere ...

-Political spaces, in which civil society groups engage with the political process as back-channels of communication or assisting in negotiation of the peace settlement ...

Religious actors' participation in Track One negotiations would be located in "political spaces" - which are just a small part of the overall picture. The other six modalities of participation could be located in the other spaces, firmly within the social peace process. For example, religious actors might mobilize mass action campaigns in "market spaces;" while high-level problem-solving workshops might constitute "intellectual spaces."

The second set of relationships is between church and state. The key vari-able here is the majority/minority status of the church. When a church has "majority" status (i.e. it is an established church, formerly established church that still commands some prestige, or a church linked to the state or a domi-nant group culture), it may be constrained in its ability to criticize and take risks. In these cases, churches, and their "official" representatives, have too much social, political and cultural power to lose. Minority religions, on the other hand, have more freedom and flexibility to be critical or "prophetic", al-though they also may be more vulnerable to harassment.

This "church-civil society-state matrix" helps us understand why religious actors have different levels of legitimacy, and how those different levels can enable or constrain their actions. High levels of legitimacy may keep religious actors too closely aligned to the politicians and ethnic elites of the state or their communal group. This means that they cannot risk going "too far" in ar-ticulating visions of peace, especially in contexts where religion has been part of the conflict. On the other hand, those who are "minority" religions or who are "mavericks" on the margins of majority religions have greater flexibility and scope to capitalize on the strengths of faith-based mediators, as outlined by Bercovitch and 
Kadayifci-Orellana. In Northern Ireland, Brewer, Higgins, and Teeney classified Methodism as a "minority" religion, even though it is a branch of Christianity and Methodists are part of the overarching "Protestant" community. Yet, Methodism was the smallest in number of the four larg-est Christian denominations (Catholic, Presbyterian and Church of Ireland [Anglican]), and its spokespersons and leaders took greater public risks during the peace process. In contrast, across the countries of the former Yugoslavia, minority religions (which also are linked to particular ethnic groups) facilitated the preservation of ethno-cultural traditions. Despite their strategic position, they did not take up a prophetic role like that of Northern Ireland's Methodists.

Brewer, Higgins, and Teeney also observed that in Northern Ireland, reli-gious peacebuilding was "individualized to lone peacemakers, independents, and mavericks" (Brewer \& Teeney 2015: 3686). These distinctions demonstrate that "official" religious representatives - the very people who governments and political parties might seek to include in peace and transition processes might be too constrained to take the risks necessary for peace. Alternatively, religious actors themselves may recognize the dangers of aligning themselves with political power. They may resist being co-opted by those powers, by taking strategic decisions to work behind the scenes or to exclude themselves from Track One negotiations. This is the basis for our argument that religious ac-tors are more likely to contribute to peace when they are excluded from direct representation in the Track One negotiations that produce peace agreements and are active in the other modalities of participation: in wider social peace processes at national or grassroots levels. Religious actors can contribute to peace processes especially if they choose to exclude themselves from Track One negotiations in order to avoid the pitfalls of becoming too closely associ-ated with political power.

\section{Northern Ireland}

No religious actors participated as official representatives of their religion in the Track One negotiations that produced the Good Friday Agreement of 1998. The negotiations, chaired by American Senator George Mitchell, were explic-itly limited to political parties. No civil society actors were invited. While this decision may seem more limiting than other peace processes, the talks were open to 
Sinn Fein once it adhered to the "Mitchell principles" of nonviolence, despite its links to the Irish Republican Army (IRA), and smaller political par-ties, some with links to loyalist paramilitary groups. This made the talks more inclusive than those which exclude parties with links to paramilitaries. The party-political structure of the talks even motivated a group of women to form a new political party, the Women's Coalition, for the specific purpose of repre-senting women's views. To some extent, the Women's Coalition also saw itself as representing the wider interests of civil society at the talks. They succeeded in securing a Civic Forum as part of the Agreement, although this was later suspended.

Nevertheless, the representatives of the political parties who participated brought their religious identities with them. Northern Ireland's two oppos-ing communities are conventionally referred to with the labels "Protestant" and "Catholic," although in recent years the more encompassing terms

"Protestant-Unionist-Loyalist (PUL)" and "Catholic-NationalistRepublican (CNR)" have been employed to capture the range of religious and political identities encapsulated in the two communities. Much of the literature on the Northern Ireland conflict classifies it as an "ethno-national" conflict, in which religion is simply an "ethnic marker" (McGarry \& O'Leary 1995; Clayton 1998; Coulter 1999). But we see the conflict as an "ethno-religious" one, convinced that religion does more than supply a superficial label for the communities in conflict. We build on the work of Mitchell (2006), who argued that religion derives its significance from five overlapping dimensions: 1) how the churches cooperate with politicians to appeal to their respective communities; 2) as the dominant boundary marker and the basis of segregation; 3) through re-ligious practices that help construct wider communities (even among those who do not go to church); 4) through religious ideas that become politically salient when constructing conceptions of self and other (even among those who do not go to church); and 5) through Calvinist/evangelical theologies that give meaning to identity for some evangelical Protestants, who exert a disproportionate influence on unionist politics. Religion also structures communal life in that most people in Northern Ireland live in segregated areas and attend religiously--segregated schools. "Mixed marriages" between Catholics and Protestants are genuinely rare, and social networks tend to be limited to one's community of birth. 
A number of scholars have argued that religion is a more important aspect of the conflict for Protestants than it is for Catholics, given its constitutive role in forming the "core" of Protestant ethnic identity (Bruce 1986, 2007; Ganiel 2008; Brewer \& Higgins 1998). Steve Bruce $(1986,2007)$ has claimed that the importance of evangelicalism for unionist identity is largely what explains the rise of the Reverend Ian Paisley, a man unique in Europe for founding not only his own denomination, the Free Presbyterian Church, but also a political party, the Democratic Unionist Party (DUP). The DUP's elected representatives are disproportionately Free Presbyterian and evangelical (Ganiel \& Dixon 2008; Tonge et al. 2014). Throughout the conflict and the period immediately after the Agreement the DUP was the smaller of the two main unionist parties, but by 2003 it had overtaken its rival the Ulster Unionist Party (UUP) (Farrington 2006). While there is evidence that the DUP surpassed the UUP in part because it softened its evangelical character, many of its representatives appeal to re-ligion and continue to be motivated by it (Ganiel 2006, 2007). When the DUP pushed for a no vote in the referendum to approve the Agreement, it was partly on religious grounds: the party argued that the release of paramilitary prison-ers, as stipulated in the Agreement, was "immoral" and that God would not look favorably on a land that allowed "terrorists" to go free.

The overlapping of religious, ethnic and political identities in Northern Ireland means that it can be difficult to untangle so-called "religious" and "sec-ular" actors. When Paisley and the DUP were participating in the negotiations for the Agreement, was it as religious or secular actors - or some combination thereof? This question seems most pertinent for Paisley and the DUP because of their willingness to wear their religion on their sleeves. But the question also could be asked of at least some politicians in all the other parties, who were regular churchgoers and who saw their politics as motivated in part by religious conviction.

The difficulty in untangling religious and secular actors in Northern Ireland alerts us to the fact that different actors will have different levels of religious legitimacy. On the one hand, the evangelicals of the DUP possess a high level of religious legitimacy. The key place of evangelicalism within PUL identity would lend support to this claim. Yet the case of Paisley and the DUP demonstrate that high levels of religious legitimacy do not necessarily make reli-gious actors uncritical advocates of peace. Such religious 
actors may be too constrained to assist in Track One negotiations, because they are so beholden to political power, and invested in preserving ethno -religious identity. Indeed, Paisley and his party walked out of the negotiations before the Agreement was reached, neatly illustrating the maxim that the exclusion of (religious) hard liners can assist negotiation processes - even if this was a freely chosen exclu-sion on the part of those who left the talks. In his account of the negotiations, Senator Mitchell (1999: 110) said as much:

... Reaching agreement without their presence was extremely difficult; it would have been impossible with them in the room.... Their absence

freed the UUP from daily attacks at the negotiating table, and gave the party room to negotiate that it might not otherwise have had.

The evangelicals of the DUP were not the only "legitimate" religious actors in Northern Ireland's peace process, however. It is beyond the scope of this article to provide a full account of the work of all of Northern Ireland's religious peace-builders. Ganiel (2008), Mitchel (2003), and Brewer, Higgins, and Teeney (2011) all have argued that some of the most significant religious peacebuilders were evangelicals working at the micro-level, who critiqued Paisley's evangelicalism and modeled a more inclusive and reconciliatory evangelical alternative. The best example of this is the activism of the organization Evangelical Contribution on Northern Ireland (ECONI). They illustrate Bercovitch and Kadayifci-Orellana's third condition about how faith-based mediators are uniquely placed to draw on resources from their own religious tradition to justify transforming conflict. ECONI used their legitimacy as evangelicals to appeal to the wider Protestant community, contributing to changes in identity and attitudes towards recon-ciliation (Ganiel 2008; Mitchell \& Ganiel 2011). These evangelicals were active in the six other modalities of participation, but not Track One negotiations (save perhaps for some politicians in the UUP or Alliance Party who shared ECONI's perspective). The evangelicals of ECONI were well-aware of the dan-gers of aligning themselves too closely with political power, 
arguing that this would compromise their ability to critique Paisley's religious nationalism. Had they been offered the opportunity to participate in Track One negotiations, it is probable they would have chosen to exclude themselves on principle. As Rev. John Dunlop, a former moderator of the Presbyterian Church, said:

The politician's job is to do the negotiations, we can't do the negotiations but we can create an environment where negotiations might have been possible. I never thought it my job to be involved in the talks as such but you were encouraging people to be involved in them (quoted in Brewer, Higgins \& Teeney 2011: 118).

As an organization rather than a denomination, ECONI also had more free-dom and flexibly to take risks than the churches themselves (Ganiel 2008). "Official" representatives of the largest Christian denominations realized they had to keep diverse constituencies on board and were relatively unwill-ing to move beyond "passive" and "negative" forms of peacebuilding (Brewer, Higgins \& Teeney 2011). The cost of maintaining legitimacy was a constraint on their ability to take risks for peace. In a way, this meant that the institutional churches excluded themselves from not just Track One negotiations, but also from some of the other modalities of participation within the social peace process. But it was not the type of self-exclusion that we see in ECONI, which sought to preserve a "prophet's" distance and avoid becoming compromised by political power. Rather, it was a type of selfexclusion that sought to preserve the churches' social position, without asking hard questions about the rela-tionships between religion, politics and conflict. Here, as explored in Brewer, Higgins, and Teeney's framework, we see how the "official" representatives of churches may be too constrained to be effective faith-based mediators.

In contrast, the inspiring work of mavericks is profiled in Brewer, Higgins, and Teeney (2011), as well as in work by Ronald Wells (2010). Two of the most striking examples of clergy active in behind-the-scenes work were Father Alec Reid, Archbishop Robin Eames from the Church of Ireland, a Protestant church and part of the Anglican Communion (see Brewer, Higgins \& Teeney 2011 for a full-er account of their activities, and McKeever 2017 on Reid). As a high-ranking church official, Eames could be considered an 
"official" representative. Yet, he took great pains to keep his own activities secret from the rest of the Church of Ireland, reflecting what was most likely an accurate belief that what he was doing in facilitating communication between loyalists, republicans, and the British and Irish governments would not be met with approval from all within the denomination.

Reid and Father Gerry Reynolds, another Redemptorist at Clonard, were the two Catholic priests most involved with the monastery's "reconciliation minis-try." Reid took the lead in initiating and sustaining behind-the-scenes negotia-tions in the early 1990s: first between Sinn Fein leader Gerry Adams and John Hume, the leader of the then-largest nationalist party, the Social Democratic and Labour Party (SDLP), and eventually including contact with the British Government; and second between Sinn Fein politicians and Protestant clergy. The Hume-Adams talks were groundbreaking due to Sinn Fein's links with the IRA. No one in Northern Ireland could be seen to be talking to "terrorists," yet Reid believed that progress was not possible without an inclusive process. The Sinn Fein/Protestant clergy talks were significant because it was the first time people from these groups had the opportunity to listen to each other in a safe space - Clonard Monastery - and to begin to understand the cultures, identi-ties, and grievances of the other side. These maverick clergy, active without the official blessing and in some cases knowledge of their denomination, were able to take risks that politicians and "official" church representatives could not - even in secret. It can be argued that these talks contributed to changes in Sinn Fein perceptions of unionism, paving the way for more successful Track One negotiations with unionist politicians when the time was ripe. Likewise, the Protestant clergy who participated gained a fuller understanding of repub-lican perspectives on the causes of the conflict and why republicans had felt armed struggle was necessary.

Reynolds took the lead in participating in public ecumenical initiatives, such as the Cornerstone Community, an ecumenical community based on an "interface" area in Belfast; the Unity Pilgrims, a group of Catholics associ-ated with Clonard who attended services in different Protestant congregations each Sunday; and the Clonard-Fitzroy Fellowship, a partnership with Fitzroy Presbyterian Church that became a model for other congregations to fol-low (Newell 2016, Wells 2010, 2004). Clonard-Fitzroy focused 
on small group events to build relationships between so-called "ordinary" people in their congregations, and organized public activities, such as inviting Adams to speak in Fitzroy. Though Reid was more central to the behind-the-scenes negotia-tions and Reynolds was more visible in public ecumenical work, they supported each other and participated in activities that the other had taken the lead on. Both Reid and Reynolds were seen as "legitimate" and sincere peacemak-ers by Sinn Fein and the CNR community - as well as by key people from the "other" community, although many Protestants would have been suspicious of them. Reid and Reynolds operated with the knowledge, though not the active public support, of Ireland's Catholic hierarchy. This gave Reid and Reynolds the freedom and flexibility to take risks - while at the same time retaining the legitimacy they had earned as faith-based mediators.

This overview of the role of Northern Ireland's religious actors in peace and transition processes has highlighted the contributions of a few key players; a longer account could have provided examples of religious actors operating in six of the seven modalities of participation - everything except direct negotia-tions that produce peace agreements. The contributions we have highlighted illustrate how religious actors in the same context may possess different levels of legitimacy. It is too simple to say that religious actors are more likely to be effective peacebuilders in cases where religious identity has been important. Rather, different levels of legitimacy either enable or constrain religious peace-builders in their work for peace. We also have demonstrated how "official" representatives of religion, even if they seem to have a high level of legitimacy in their community, may be more constrained in peace and transition processes. Northern Ireland is not a case where official religious representatives were included in Track One negotiations, thus making it difficult to answer the ques-tion whether they would have made positive contributions. Nevertheless, we have noted that Northern Ireland's mavericks were wary of entanglement with state power, or of becoming too closely aligned with the political power holders in their own communities. This is a different sort of principled stance than the one taken by the DUP in walking out of the talks. Brewer, Higgins, and Teeney (2011: 118) lamented that the churches would not have been viewed as helpful contributors in the negotiations: "They were excluded, in short, because the churches were not expected to be unanimously in favor of 
compromise: a sad reflection." But, if they had been included in negotiations, this could have com-promised their ability to contribute in the other six modalities. The exclusion of religious actors from Track One negotiations (the political peace process) enabled them to avoid the pitfalls of a too close alignment with political power. Ultimately, this empowered religious actors to more effectively contribute to the social peace process.

\section{Bosnia and Herzegovina}

As in Northern Ireland, no religious actors participated as official representa-tives of their religion in the Track One negotiations that produced the Dayton Accords of 1995. The negotiations were rather exclusive with parties being rep-resented by political leaders, and their diplomatic envoys: President of the Federal Republic of Yugoslavia Slobodan Miloševič, President of Croatia Franjo Tudman, and President of Bosnia and Herzegovina Alija Izetbegović. Despite being presidents of three different countries, they in fact represented three ethno-religious groups - Serbs, Croats and Bosniaks - and their respective ethnically-based political entities and parties in Bosnia and Herzegovina.5 The exclusion of "official" religious leaders was understandable for two reasons: first, more so than in Northern Ireland, religion was already seen as a negative factor in contributing to the conflict. The inclusion of religious leaders could have potentially harmed the process by redirecting the focus from core to sec-ondary issues, or inflaming religiously-tinged emotions. As in Northern Ireland with Paisley and the DUP, political representatives participating in the talks often presented themselves as adherents to their respective religions. These political leaders used religion to perpetuate narratives of the past, identity and belonging, which justified division and conflict. Despite their communist past, Miloševič and Tudman utilized their respective religions as important means in their nationalist and nation-building efforts after the fall of communism. Unlike Miloševič and Tudman, Izetbegović, who fell into disfavor of the com-munist regime for his academic and political activities related to Islam, was an anti-communist opponent. Yet, he nourished ethno -religious nationalism by establishing an ethnically-based political party with a largely Muslim charac-ter in 1989, similar to those of Bosnian Serbs and Croats. 
Second, the inclusion of religious actors was not considered either by na-tional political leaders or by the international community for principled rea-sons: in addition to the fact that the conflict was fought by political and military actors, the Dayton peace talks were led and coordinated by the international community, in particular the representatives of the United States, Russia and the European Union, with the presence of the United Nations, North Atlantic Treaty Organization, and British, French, German, and other countries' repre-sentatives. The aim of the talks was to unite the three different groups within one geopolitical territory and to build a state according to international law,

5 Leaders of political entities and militias of Bosnian Croats and Serbs as well as Croatian Serbs, including those accused by and under the arrest of the International Criminal Tribunal for the former Yugoslavia, were excluded from the negotiations.

and not to build a religious state or reconcile the religions (Interview by the first author with a European Union official, 2015). The Dayton Accords refer to ethno-religious reconciliation as an effect of the peace agreement and an aim which should be promoted in society. In international peace negotiations, the emphasis has been on the involvement of secular, non-religious, leaders, such as representatives of political parties, states and militia groups. The exclusion of religious leaders in the peace talks that led to the Dayton agree-ment is therefore reasonable from the perspective of international law - as was the case with the Good Friday Agreement. International actors did not see religious identities as root causes of the conflict. American diplomat Richard Holbrooke, the lead mediator and the architect of the Dayton Accords, argued that political leaders used ethnic confrontation for personal political and fi-nancial gain (Holbrooke 1998). Religious actors therefore did not represent the best suitable candidates for a negotiating table.

Despite the exclusion of official religious actors from Track One negotia-tions, the shadow of religion loomed over the conflict, the talks, and the on-going transition process. As in Northern Ireland, religion had been bound up with ethnic identity. After the breakup of Yugoslavia in 1991-1992, Bosnia and Herzegovina became the site of an armed conflict involving three parties de-marcated along ethnic and religious lines: Muslim Bosniaks, Orthodox Serbs and Catholic Croats. More so than in Northern Ireland, scholars have 
used the term "ethno-religious" to describe this conflict. Ethnoreligious identities have characterized the life of people in this region for centuries. Religious practices were maintained even during the anti-religious communist times (Mekić 2017: 33). Functioning more as countryside folklore rather than as faith, religious practices have preserved cultural traditions of ethnic groups. The collapse of communism brought Yugoslavia's religions an unprecedented level of free-dom, resulting in a rapid religious revival. Religions fully utilized this situa-tion to increase their influence over their adherents (Mekić 2017: 33, 37). This revival led to a strengthening of ethnic and national identities, mainly in rural areas. These identities coexisted with strong secular attitudes, which were more characteristic in urban areas (Bennett 1997; Ramet 1996).

It is therefore not surprising that religious identities became a dominant feature in the Bosnian war. Kivimäki, Kramer, and Pasch argued that, whereas the conflict was mainly about power and territorial issues, identity played an important role in both fueling and maintaining the conflict. The "centrality of identity-based conflict motives" was a major factor, which was exploited by both religious and political leaders (Kivimäki, Kramer \& Pasch 2012: 5). The conflict in Bosnia and Herzegovina became a paramount example of a war in which group identity formed the basis of politics and was the cornerstone for the mobilization of popular support (Kaldor 2013). Ethno-religious identities were nourished by the narratives of a complex history, which were exploited by political and religious leaders for their nationalist propaganda. They referred to the historic oppression of their respective religions or religious persecu-tion, which exacerbated the perceived cleavages among the different groups. Historical events were perceived as unjust and were revived during the war, making it difficult to disconnect ethnicity from religion (Kivimäki, Kramer \& Pasch 2012).

For these reasons, some have claimed that the conflict was largely about religion (Robinson 2007; Rubin 1999). However, it would be more correct to argue that religion was used by political leaders as a tool for their ethno-na-tionalist objectives (Kivimäki, Kramer \& Pasch 2012: 16). By involving religion in their politics, political leaders and parties created tension and hatred among the groups (Stefanov 2012). For instance, seeing himself as a defender of the 
Orthodox faith, President of Republika Srpska Radovan Karadžić, who was charged with war crimes, crimes against humanity, and genocide, described his war against Bosnian Muslims as "just and holy" (BBC 2010). The war also can be seen as a result of failed state-building in Yugoslavia. The Serb elites governed along ethnoreligious lines instead of creating an inclusive society. As a result, the citizens of ex-Yugoslavia continued to identify primarily with their ethno-religious identities. In a context where ethno-national identity is so bound up with religion, it is easy to see how religious leaders could claim and command high levels of legitimacy. However, that legitimacy was largely dependent on religious actors' perceived commitment and loyalty to the ethnic group. Similar to some religious leaders in Northern Ireland, they were unwilling or unable to challenge how religion was used by their community to promote division and conflict. High levels of legitimacy would ultimately constrain peacebuilding.

Indeed, while Northern Ireland has been used to provide examples of many constructive examples of religious peacebuilding (Appleby 2000), Bosnia and Herzegovina has been seen as a case where religion contributed disproportionately to conflict. Religious leaders possessed significant leverage, legiti-macy, and credibility among their followers - attributes which according to Bercovitch and Kadayifci-Orellana make faith-based actors suitable for mediation. They were seen as trustworthy and as leaders with moral and spiritual authority by their followers. However, they lacked a country-wide and inclusive credibility acceptable by all three ethnoreligious groups. Religious leaders also did not advocate reconciliation and forgiveness, demonstrating a lack of motivation for mediation and peace. Peace-promoting voices either did not exist or were not heard sufficiently (Silvestri \& Mayall 2015). Religious leaders contributed to a radicalization of the ethno-religious groups by promoting nationalist narratives and the language of hatred (Sells 1998; Velikonja 2003). The Serbian Orthodox Church, including the patriarch, has criticized Miloševič and demanded his resignation on several occasions. Yet, the Church understood itself as a guardian of Bosnian Serbs. Priests, with support of their church hierarchy, gave blessings and prayers for soldiers and military before battles (Harden \& Gall 1999; Sells 1998). Seeing themselves as protectors of their respective groups, the Serbian Orthodox Chureh, the Croatian Catholic Church and Muslim clerics in Bosnia supported their political leaders (Sells 1998). 
Religious representatives of the three groups opposed any reconciliatory solution. All three groups expressed their demands in terms of justice, given the fact that all three religious groups suffered human and material losses. Although religion was an important aspect of the identities of disputants - one of Bercovitch and Kadayifci- Orellana's conditions for faith-based mediation religious leaders would have been neither effective negotiators nor mediators due to their lack of motivation for a peace settlement.

The different positions of the religious groups in something akin to Brewer, Higgins, and Teeney's "religion- state-civil society matrix"6 meant they were in asymmetric power-positions. The Serbian Orthodox Church was more em-powered due to its closer relationship with the Serbian state and due to the support of other Orthodox Churches. Bosnian Muslims justifiably felt more victimized. Further, including the representatives of the three religious groups would have left out other tiny groups, such as Jews, and those who are not affiliated with any religion. Brewer, Higgins, and Teeney's judgment for the exclusion of religious actors in Northern Ireland also holds true for Bosnia and Herzegovina: they were excluded because they were not expected to be unanimously in favor of compromise. Like the response of Paisley and the DUP to the Good Friday Agreement, the responses of churches and clerics to the Dayton Accords confirm that they were not in favor of compromise. The Serbian Orthodox Church openly criticized the Dayton Accords. They saw the conditions of this agreement as a step that would undermine the interests of the Bosnian Serbs. Leaders of the Catholic and Muslim communities also did little to support the implementation of the agreement. Instead of supporting inter-religious activities, both the Catholic Church and Muslim clerics advo-cated legal actions that reflect religious doctrines and have the potential to further perpetuate divisions. Despite being uniquely placed for transforming a conflict shaped by a long-standing and hostile history, religious leaders did not

6 Here we substitute the term "religion" for "church" in recognition of the inter-religious ele-ment in Bosnia and Herzegovina. 
resort to resources from their own religious traditions to promote peace and reconciliation.

International religious leaders also did little to pacify their "brothers and sisters in faith" - save for an occasional official statement: a paradigmatic form of passive and negative peacemaking. Eastern Orthodox churches, especially the Russian and Greek Orthodox Churches, demonstrated their moral sup-port to Bosnian Serbs. The Greek Orthodox Church even honored and praised Karadžić for defending Orthodoxy and peace (Velikonja 2003: 265). The Vatican played a rather controversial part by supporting the drives of the Croats for in-dependence. Bosnian forces received support from Arabic countries (Berkley Center 2013; Partos 1997; Sells 1998). As Küng and Kuschel claimed, religious leaders failed to fully utilize the opportunities provided by the positive, peace-- promoting messages of their religions; religions "neglected $[\ldots]$ to engage in mourning, honestly confess the crimes which had been committed by all sides in the course of the centuries, and ask one another for mutual forgiveness" (Küng \& Kuschel 1993: 43-44). The failure of the international religious com-munity also affected financial and human resources - one of the attributes of faith-based mediation. But with national and international level religious lead-ers largely absent in all seven modalities of participation, some international religious organizations picked up the slack. These included Eurodiaconia, the Council of European Churches (CEC), and the World Council of Churches (WCC), as well as independent denominational organizations. They have promoted conflict resolution and interreligious dialogue in different forms at the national and local level (Merdjanova \& Brodeur, 2010). However, these international religious actors lacked sufficient leverage and legitimacy, which limited their influence on national and local religious leaders and the wider population.

Despite their exclusion from the official peace negotiations, religious actors could have become involved in other modalities of the peace and transition process, in particular the social peace process, as was the case in Northern Ireland. However, national religious actors needed international support (and pressure) to enter into ecumenical and inter-faith dialogue. International ac-tors, such as the WCC, the World Conference on Religions for Peace (WCRP), and Mercy Corps International, initiated programs for peacemaking among the religions in the country, including the Jewish community. In 1997, the WCRP brought together Orthodox, 
Catholic, Muslim and Jewish religious lead-ers to begin a process of dialogue. These activities led to the establishment of the InterReligious Council of Bosnia and Herzegovina (WSCF Europe 2015). Youth organizations such as the Ecumenical Council of Europe and the Forum of European Muslim Youth and Student Organizations launched their own and joint initiatives, including workshops on conflict resolution. With the arrival of international actors, national religious actors have started to engage in symbolic acts of conflict resolution and peacemaking. Some local religious leaders and communities have gradually started to talk and to work together to build sustainable peace. Young religiously-devoted people rather than older generations have been more prone to participate in conflict resolution and ecumenical or inter-religious activities. Also, women's groups have taken a leading role in interreligious conflict resolution activities, including public participation. Independent religious councils have been established to help with conflict resolution and reconciliation between the religious communities (Merdjanova \& Brodeur 2010; Merdjanova 2013; Spahic-Siljak 2012, 2014).

Despite the slow pace in ecumenical and inter-religious dialogue, the in-creasing involvement of, especially young, religious leaders and laypeople in inter-faith activities demonstrates the strength of religious mavericks. In contrast to official representatives of religion, these actors may be less constrained by the negative impacts of legitimacy. Their micro-level, inter-faith activities are part of the "social" peace process. They are located in what Brewer, Higgins, and Teeney frame as intellectual, institutional, and market spaces rather than political ones, demonstrating that religious actors are more likely to play a constructive role in social peace processes than Track One negotiations. Indeed, these activities do not focus on questions of political division, territorial changes, and power distribution. However, they support peaceful coexistence between the different ethno-religious groups, which is an important aim of the peace agreement. The Dayton Accords refer to the respect for religious and ethnic minorities, the prevention of ethnic or religious hostility or hatred, and practical measures to ensure these goals as well as provisions on building monuments of religious importance and the maintenance of religious heritage (United Nations 1995). The national and local inter-religious activities that aim at these objectives are congruent 
with inclusive post-agreement mechanisms, public participation and campaigns - three out of Paffenholz's seven modalities of participation in peace and transition processes.

The case of Bosnia and Herzegovina demonstrates that, despite their ab-sence in the political peace process (Track One negotiations), religious actors still have an important role to play in the social peace process, particularly the implementation of peace agreements. The exclusion of religious actors from direct Track One negotiations was understandable. Religious leaders had legitimacy in that they could be considered to be closely aligned with their ethnic group - as it was in the case of Paisley and the DUP. But this type of legiti-macy most probably would have proved a hindrance to compromise, as dem-onstrated by religious leaders' opposition to the Dayton Accords. Nevertheless, religious actors have started to become involved in local peacemaking efforts, especially grass-roots conflict resolution activities and symbolic religious ges-tures. Like Northern Ireland, Bosnia and Herzegovina is an example of a peace and transition process where religious actors have greater potential to contrib-ute to peace when they are excluded from direct participation in Track One negotiations.

\section{Conclusion}

This article has used a comparative case study approach to analyze the strengths and limitations of two foundational, theoretical frameworks con-cerned with the role of religious actors in peace and transition processes: those of Bercovitch and KadayifciOrellana, and Brewer. Understanding the role of religious actors in peace and transition processes is an urgent task because re-ligion has increasingly been a factor in conflicts and peace processes through-out the world. Identifying conditions under which religious actors are best placed to contribute constructively in peace and transition processes is crucial in a post-September 11th world where some commentators and policy makers assert that religion cannot make constructive contributions to peace.

The most important contribution of Bercovitch and KadayifciOrellana's framework is helping us understand when faith-based actors can be especially effective at mediation, bringing perspectives to peace and transition processes that secular actors cannot. They make a strong theoretical case for the inclu-sion of 
faith-based mediators at every stage of a peace and transition process, especially in contexts where religious actors have legitimacy due to the impor-tance of religion as a factor in conflict. Yet, they do not allow much scope for taking into account the limitations of faith-based mediators. Brewer, Higgins, and Teeney's analytical framework provides some tools for understanding their limitations. It helps us to see more clearly that religious actors possess dif-ferent levels of legitimacy. High levels of legitimacy, i.e. when religious leaders have strong relationships with political power holders in their ethnic group, may in fact constrain religious actors from taking the risks necessary for peace. This means that the "official" representatives of religions, who policymakers and politicians might instinctively turn to when seeking to include religion in negotiations, may be more likely to obstruct peace rather than contribute to it. Further, Brewer, Higgins, and Teeney observe that religious peacebuilders tend to be more effective in "social" rather than "political" peace processes. Different religious actors, with different levels of legitimacy within their ethno-religious groups, occupy different "strategic social spaces" within civil society.

This means that they can contribute to peacebuilding at a wide range of lev-els (from macro to micro), including all seven modalities of peace and tran-sition processes. Their contributions may be public or behind closed doors. "Minority" religions or "mavericks" on the margins of "majority" religions are more likely to take the risks necessary to achieve peace, precisely because they are not constrained by close relationships with political power. While they may be constrained due to their small size and relative lack of resources, empirical evidence from our two case studies testifies to their effectiveness. Religious peacebuilders have limitations, but the factors that may limit a religious peace-builder in one modality (i.e. level of legitimacy), may strengthen their contri-bution in another modality.

Our comparison of Northern Ireland and Bosnia and Herzegovina pro-vided concrete examples of the strengths and limitations of religious actors, confirming aspects of both theoretical frameworks. Undoubtedly, Brewer, Higgins, and Teeney's analytical framework could be expected to work well in Northern Ireland, as this was the context from which it was developed. At the same time, it also proved useful in Bosnia-Herzegovina, a conflict with inter-religious (not just intra-Christian) dimensions. However, it should 
be noted that Bosnia-Herzegovina provided some counter-evidence to the argument that minority religions are more likely to contribute to peace and transition processes. Perhaps it could be said that Bosnia-Herzegovina's minority reli-gions did not grasp the unique peacebuilding opportunities that were available to them as minority religions. Regardless, it is clear that the insights of both of the theoretical frameworks have promise for application beyond Christian contexts.

Ultimately, we conclude that the inclusion of religious actors can be of great benefit to peace processes. While their contributions to the macro (state) level of political negotiations may be limited - so much so that the best decision may be to exclude them from such negotiations - religious actors come into their own when they engage in the social peace process. Indeed, religious ac-tors can contribute to peace processes especially if they choose to exclude them-selves from Track One negotiations in order to avoid the pitfalls of becoming too closely associated with political power. This is a very different type of self-exclusion than the type taken by groups which wish to capitalize on the fail-ures of peace agreements. It is a self-exclusion that enables religious actors to act more effectively as watchdogs on political power holders, enabling them to offer "prophetic" challenges to those who fail to compromise. Those who are working with religious actors in peace and transition processes should be aware that some religious actors may choose to exclude themselves from Track One negotiations for this reason. They should be alert to how they can work with them across the other six modalities, actively seeking to include them in these aspects of peace and transition processes.

\section{References}

Abu-Nimer, Mohammed (2003). Nonviolence and Peace Building in Islam: Theory and

Practice. Gainesville: University Press of Florida.

Appleby, R. Scott (2001). "Religion as an Agent of Conflict Transformation and Peacebuilding," in Chester A. Crocker, Pamela R. Aall, and Fen Osler Hampson, editors, Turbulent Peace: The Challenges of Managing International Conflict, 2nd ed. Washington, D.C.: United States Institute of Peace Press, 821-840. 
Appleby, R. Scott (2000). The Ambivalence of the Sacred: Religion, Violence, and

Reconciliation. Lanham, MD: Rowman \& Littlefield.

Appleby, R. Scott, Robert J. Schreiter and Gerard Powers (2010).

Peacebuilding: Catholic

Theology, Ethics, and Praxis. Maryknoll, N.Y: Orbis Books.

Bennett, Christopher (1997). Yugoslavia's Bloody Collapse: Causes,

Course and

Consequences. New York: New York University Press.

$B B C$ (2010). "Karadzic Defends Bosnian Serb 'Holy' Cause at

Trial." March 1, at: http://

news.bbc.co.uk/1/hi/world/europe/8542297.stm.

Bercovitch, Jacob (1986). "International Mediation: A Study of the Incidence, Strategies

and Conditions of Successful Outcomes." Cooperation and Conflict 21, 3: 155-68.

Bercovitch, Jacob and Ayse S. Kadayifci-Orellana (2009).

"Religion and Mediation: The Role of Faith-Based Actors in International Conflict Resolution." International Negotiation 14, 1: 175-204.

Berkley Center for Religion, Peace \& World Affairs (2013).

Bosnia: Ethno-Religious Nationalisms in Conflict, Washington,

D.C.: Georgetown University. At: http://

repository.berkleycenter.georgetown.edu/130801BCBosniaEthno

ReligiousNational ismsConflict.pdf.

Boulding, Elise (1984). "Two Cultures of Religion as Obstacles to Peace."

Zygon: Journal

of Religion \& Science 21, 4: 501-518.

Brewer, John D. and Gareth Higgins (1998). Anti-Catholicism in Northern Ireland, 1600- 1998: The Mote and the Beam. Basingstoke: Macmillan Press.

Brewer, John D., Gareth Higgins and Francis Teeney (2010). "Religious Peacemaking:

A Conceptualisation." Sociology 44, 6: 1019-37.

Brewer, John D. (2011). Religion, Civil Society and Peace in Northern

Ireland. Oxford:

Oxford University Press.

Brewer, John D. and Francis Teeney (2015). "Violence, Tolerance and Religious Peacebuilding in Northern Ireland," in Stanley D. Brunn, editor, The Changing World Religion Map, vol. 5. London: Springer, 3649-3668. 
Bruce, Steve (1986). God Save Ulster! The Religion and Politics of Paisleyism. Oxford:

Clarendon Press.

Bruce, Steve (2007). Paisley: Religion and Politics in Northern Ireland. Oxford: Oxford University Press.

Brudholm, Thomas and Thomas Cushman, eds. (2009). The Religious Response to Mass Atrocity. Cambridge: Cambridge University Press.

Cavanaugh, William T. (2007). "Does Religion Cause Violence?

Behind the Common Question Lies a Morass of Unclear Thinking."

Harvard Divinity Bulletin 35, 2, 3: 22-35. Cavanaugh, William T. (2009). The Myth of Religious Violence: Secular Ideology and The

Roots of Modern Conflict. Oxford: Oxford University Press.

Clayton, Pamela (1998). "Religion, Ethnicity and Colonialism as Explanations of the Conflict in Northern Ireland," in David Miller, editor, Rethinking Northern Ireland. London: Longman, 40-54.

Coulter, Colin (1999). Contemporary Northern Irish Society: An Introduction.

London:

Pluto Press.

Farrington, Christopher (2006). Ulster Unionism and the Peace

Process in Northern Ireland. Basingstoke: Palgrave Macmillan.

Ganiel, Gladys (2006). “Ulster Says Maybe: The Restructuring of Evangelical Politics in

Northern Ireland." Irish Political Studies 21, 2: 137-155.

Ganiel, Gladys (2007). "Preaching to the Choir: An Analysis of DUP

Discourses about

the Peace Process." Irish Political Studies 22, 3: 303-320.

Ganiel, Gladys (2008). Evangelicalism and Conflict in Northern Ireland. New York:

Palgrave Macmillan.

Ganiel, Gladys and Paul Dixon (2008). "Religion in Northern Ireland: Rethinking Fundamentalism and the Prospects for Conflict Transformation." Journal of Peace Research 45, 3: 419-36.

Gopin, Marc (2002). Between Eden and Armageddon: The Future of World Religions,

Violence, and Peacemaking. Oxford: Oxford University Press.

Gopin, Marc (2001). "Forgiveness as an Element of Conflict Resolution in Religious Cultures: Walking the Tightrope of 
Reconciliation and Justice," in Mohammed Abu-Nimer, editor, Reconciliation, Justice, and Coexistence: Theory and Practice. Oxford: Lexington Books, 87-99.

Harden, Blaine and Carlotta Gall (1999). "Crisis in the Balkans:

The Serbian Orthodox: Church of Milosevic's Rise Now Sends

Mixed Message," The New York Times, July 4. At:

http://www.nytimes.com/1999/07/04/world/crisis-balkans-

serbian-orthodox-church-milosevic-s-rise-now-sends-mixed-

message.html.

Hitchens, Christopher (2009). God Is Not Great: How Religion Poisons

Everything. New

York: Twelve.

Holbrooke, Richard (1999). To End a War. New York: Random House.

Huntington, Samuel P. (1993). "The Clash of Civilizations?" Foreign Affairs 72, 3: 22-49.

Huntington, Samuel P. (2002). The Clash of Civilizations and the Remaking of World Order. New York: Free Press.

Juergensmeyer, Mark (1993). The New Cold War? Religious

Nationalism Confronts the Secular State. Berkeley; London:

University of California Press.

Juergensmeyer, Mark (2003). Terror in the Mind of God: The Global Rise of Religious

Violence. 3rd ed., rev. and updated. Berkeley: University of California Press.

Kadayifci-Orellana, S. Ayse (2009). "Ethno-Religious Conflicts:

Exploring the Role of Religion in Conflict Resolution," in Jacob

Bercovitch, Victor Kremenyuk and I. William Zartman, editors,

The SAGE Handbook of Conflict Resolution. London: Sage, 264280.

Kaldor, Mary (2013). New and Old Wars: Organised Violence in a Global Era, 3rd ed.

Cambridge: Polity.

Kivimäki, Timo, Marina Kramer, and Paul Pasch (2012). The

Dynamics of Conflict in the Multi-Ethnic State of Bosnia and

Herzegovina. Sarajevo: Friedrich-Ebert Stiftung.

Krause, Kenneth (2015). "Religion, Violence, and Terrorism." Skeptic 20, 1: 48-56.

Marsden, Lee, ed. (2012). The Ashgate Companion to Religion and Conflict Resolution. Farnham: Ashgate.

McGarry, John and Brendan O'Leary (1995). Explaining Northern Ireland: Broken 
Images. Oxford: Wiley-Blackwell.

McKeever (2017). One Man, One God: The Peace Ministry of Fr Alec Reid CSsR. Dublin:

Redemptorist Communications.

Mekić, Sejad (2017). A Muslim Reformist in Communist Yugoslavia: The Life and Thought

of Husein Dozo. London: Routledge.

Merdjanova, Ina (2013). Rediscovering the Umma: Muslims in the Balkans between

Nationalism and Transnationalism. Oxford: Oxford University Press.

Merdjanova, Ina and Patrice Brodeur (2010). Religion as a

Conversation Starter: Interreligious Dialogue for Peacebuilding

in the Balkans. London: Bloomsbury Academic.

Michel, Thomas S. J. (2008). "Peaceful Movements in the Muslim

World," in Thomas F. Banchoff, editor, Religious Pluralism, Globalization, and World Politics. Oxford: Oxford University

Press, 239-243.

Mitchel, Patrick (2003). Evangelicalism and National Identity in Ulster, 1921-1998. Oxford:

Oxford University Press.

Mitchell, Claire (2006). Religion, Identity and Politics in Northern Ireland.

Aldershot:

Ashgate.

Mitchell, Claire and Gladys Ganiel (2011). Evangelical Journeys: Choice and Change in a

Northern Ireland Religious Subculture. Dublin: UCD Press.

Mitchell, George (1999). Making Peace: The Inside Story of the Making of the Good Friday

Agreement. London: William Heinemann.

Newell, Ken (2016). Captured by a Vision. Newtownards: Colourpoint Books.

Omer, Atalia, R. Scott Appleby and David Little (2015). The

Oxford Companion of Religion, Conflict and Peacebuilding.

Oxford: Oxford University Press.

Paffenholz, Thania (2014). "Civil Society and Peace Negotiations: Beyond the Inclusion-

Exclusion Dichotomy." Negotiation Journal 30, 1: 69-91.

Partos, Gabriel (1997). "Religion and Nationalism in the Balkans:

A Deadly Combination?" in Martin E. Marty and R. Scott Appleby, editors, Religion, Ethnicity, and Self-Identity: Nations in Turmoil, 89-124. Hanover: University Press of New England. 
Ramet, Sabrina Petra (1996). 'Nationalism and the 'Idiocy' of the

Countryside: The

Case of Serbia." Research Gate 19: 70-87.

Rapoport, David C. (1992). "Some General Observations on Religion and Violence," in Mark K. Juergensmeyer, editor, Violence and the Sacred in the Modern World. London: Frank Cass, 118-140.

Robinson, B. A. (2007). "Religious Aspects of the Yugoslavia Kosovo Conflict". Religious Tolerance. Ontario Consultants on Religious Tolerance. At: http://www .religioustolerance.org/war_koso.htm.

Rubin, Alissa J. (1999). "Religious Identity at the Heart of Balkan War." Los Angeles Times. 18 April, at: http://articles.latimes.com/1999/apr/18/news/mn-28714.

Said, Abdul Aziz, Nathan C. Funk and Ayse S. Kadayifci, (2001). Peace and Conflict Resolution in Islam: Precept and Practice. Lanham, MD: University Press of America.

Sampson, Cynthia (1994). "To Make the Real Bond Between Us All: Quaker Conciliation During Nigerian Civil War," in Douglas Johnston and Cynthia Sampson, editors, Religion: the Missing Dimension of Statecraft. Oxford: Oxford University Press.

Sampson, Cynthia and John Paul Lederach (2000). From the Ground up: Mennonite Contributions to International Peacebuilding. Oxford: Oxford University Press.

Sells, Michael A (1998). The Bridge Betrayed: Religion and Genocide in Bosnia, new ed.

Berkeley: University of California Press.

Silvestri, Sara and Mayall, James (2015). The Role of Religion in Conflict and Peacebuilding London: British Academy.

Spahic-Siljak, Zilka (2014). Shining Humanity: Life Stories of Women in Bosnia and

Herzegovina. Acmbridge: Cambridge Scholars Publishing.

Spahic-Siljak, Zilka (2012). Contesting Female, Feminist, and Muslim Identities - Post-Socialist Contexts of Bosnia and Herzegovina and Kosovo. Sarajevo: CIPS, University of Sarajevo.

Stefanov, Janko (2012). Peaceful Life in a Land of War: Religion \& the Balkan Conflicts. World Student Christian Federation - 
Europe, at: http://wscf-europe.org/mozaik -issues/peaceful-lifein-a-land-of-war-religion-and-the-balkan-conflicts/.

Svensson, Isak (2012). Ending Holy Wars: Religion and Conflict Resolution in Civil Wars. St Lucia, Queensland: University of Queensland Press.

Toft, Monica Duffy, Daniel Philpott, and Timothy Samuel Shah (2011). God's Century:

Resurgent Religion and Global Politics. New York: W.W. Norton and Company.

Tonge, Jonathan, Maire Braniff, Thomas Hennessey, and James W.

McAuley (2014). The Democratic Unionist Party: From Protest to Power. Oxford: Oxford University Press.

United Nations (1995). Agenda Item 28: the Situation in Bosnia and Herzegovina, Attachment: General Framework Agreement for Peace in Bosnia and Herzegovina. New York: United Nations General Assembly/ Security Council, A/50/790 \& S/1995/999, Nov. 30 . At: http://peacemaker.un.org/sites/peacemaker.un.org/files/ BA_951121_DaytonAgreement.pdf.

Velikonja, Mitja (2003). Religious Separation and Political Intolerance in Bosnia-Herzegovina. College Station: Texas A\&M University Press.

Wanis-St. John, Anthony (2006). "Back Channel Negotiation: International Bargaining in the Shadows." Negotiation Journal 22, 2: 119-144.

Wanis-St. John, Anthony and Kew Darren (2008). "Civil Society and Peace Negotiations:

Confronting Exclusion." International Negotiation 13, 1: 11-36. Wells, Ronald (2004). Friendship Towards Peace: The Journey of Ken Newell and Gerry Reynolds. Dublin: Columba.

Wells, Ronald (2010). Hope and Reconciliation in Northern Ireland: The Role of Faith-Based Organisations. Dublin: Liffey Press.

Weingardt, Markus A. (2008). "Das Friedenspotential von Religionen in Politischen Konflikten: Beispiele Erfolgreicher Religionsbasierter Konfliktintervention," in Manfred Brocker and Mathias Hildebrandt, editors, Friedensstiftende Religionen? Religion und die Deeskalation Politischer Konflikte. Wiesbaden: VS Verlag für Sozialwissenschaften, 299-327.

Weingardt, Markus A. (2007). Religion Macht Frieden: Das Friedenspotential von Religionen in politischen Gewaltkonflikten. Stuttgart: Kohlhammer. 
WSCF Europe (2015). History of the Interreligious Council of Bosnia \& Herzegovina. Wrold Student Christian Federation Europe. At: http://wscf-europe.org/news/ history-of-theinterreligious-council-of-bosnia-and-herzegovina/. 